\title{
The silicon content of beer and its bioavailability in healthy volunteers
}

\author{
Supannee Sripanyakorn ${ }^{1,2}$, Ravin Jugdaohsingh ${ }^{1}$, Hazel Elliott ${ }^{1,2}$, Caroline Walker ${ }^{3}$, \\ Payal Mehta ${ }^{2}$, Sera Shoukru ${ }^{2}$, Richard P. H. Thompson ${ }^{1}$ and Jonathan J. Powell ${ }^{1,2,4 *}$ \\ ${ }^{1}$ Gastrointestinal Laboratory, The Rayne Institute, St Thomas' Hospital, London SE1 7EH, UK \\ ${ }^{2}$ Department of Nutrition and Dietetics, King's College London, 150 Stamford Street, London SE1 8WA, UK \\ ${ }^{3}$ Brewing Research International, Lyttel Hall, Nutfield, Surrey RH1 $4 H Y$, UK \\ ${ }^{4}$ MRC Human Nutrition Research, Elsie Widdowson Laboratory, Fulbourn Road, Cambridge CB1 9NL, UK
}

(Received 26 July 2003 - Revised 25 November 2003 - Accepted 6 December 2003)

Dietary $\mathrm{Si}$, as soluble orthosilicic acid (OSA), may be important for the growth and development of bone and connective tissue. Beer appears to be a major contributor to Si intake, although the Si content of beer and its bioavailability in human subjects have not been well established. Here we investigated the Si content of different beers and then estimated Si absorption from beer in healthy volunteers. The Si content of seventy-six different beers was estimated using inductively coupled plasma optical emission spectrometry and one of the beers, used in the ingestion study, was ultrafiltered to determine OSA content. Next, following the ingestion of 0.6 litres beer ( $22.5 \mathrm{mg} \mathrm{Si}$; $4.6 \%(\mathrm{v} / \mathrm{v})$ ethanol), serum and urinary Si levels were measured in nine healthy volunteers over a $6 \mathrm{~h}$ period. A solution of OSA was similarly investigated as a positive control and water and $4.6 \%$ ethanol as negative controls. The mean Si level of beer was $19 \cdot 2$ (SD 6.6) $\mathrm{mg} / \mathrm{l}$; the median Si level was $18.0 \mathrm{mg} / \mathrm{l}$. There was no significant difference in the Si levels of the different beers by geographical origin or type of beer. Serum and urinary Si levels increased considerably following the ingestion of beer or a solution of OSA but not with the ingestion of either $4.6 \%$ ethanol or water. The ultrafilterability of Si from beer (about $80 \%$ ) and its absorption in volunteers (about $55 \%$ ) was comparable with that of a solution of OSA suggesting that $\mathrm{Si}$ in beer is present chiefly in a monomeric form and is readily bioavailable.

Beer: Silicon: Bioavailability

$\mathrm{Si}$, as the soluble orthosilicate anion $\left(\mathrm{Si}(\mathrm{OH})_{4} \rightleftharpoons\right.$ $\left.\mathrm{Si}(\mathrm{OH})_{3} \mathrm{O}^{-}+\mathrm{H}^{+}\right)$(Iler, 1979), has been reported as important for the growth and development of bone and cartilage in animals (Carlisle, 1986). More recently, supplementation with oral $\mathrm{Si}$ reduced bone loss and induced bone formation in ovariectomised rats (Rico et al. 2000). Si supplementation also increased femoral bone mineral density in osteoporotic women compared with a placebo (Eisinger \& Clairet, 1993). Recently, we have shown that $\mathrm{Si}$ increased type I collagen synthesis and the differentiation of human osteoblast-like cells (Reffitt et al. 2003), and that dietary $\mathrm{Si}$ intake correlated with bone mineral density in men and premenopausal women but not in post-menopausal women. This effect is attributed to the metabolic (bone-forming) quality of soluble silicate (Tucker et al. 2001; Jugdaohsingh et al. 2004). Nielsen (2002) recently showed that rats fed an Si-deficient diet had increased plasma levels and urinary excretion of type I collagen breakdown products. This indicates an increased bone resorption and, taken together, the available data suggest that $\mathrm{Si}$ is involved in the regulation of bone formation and bone turnover by affecting extracellular matrix glycoprotein synthesis.

Dietary intake is the sole source of bioavailable Si (Pennington, 1991; Van Dyck et al. 1999; Jugdaohsingh et al. 2002). Dietary Si intake in the USA is about $20-50 \mathrm{mg} /$ person per $\mathrm{d}$, with the highest intakes in males and younger adults (Pennington, 1991; Uthus \& Seaborn, 1996; Jugdaohsingh et al. 2002). Similar intakes have been estimated for the British diet (Bowen \& Peggs, 1984). Whole grains have high levels of $\mathrm{Si}$, especially oats, barley, rice bran, and wheat bran (Schwarz \& Minle, 1972; Pennington, 1991), and hence grain products, such as bread, rice, breakfast cereals and pastry products, are also high in Si. However, these grain products use the edible caryopsis of the cereal, whereas $\mathrm{Si}$ (phytolithic $\mathrm{Si}$ ) is found almost solely in the husk (Broadhurst, 1999). Hence, the Si content of cereal-based foods is mainly attributable to cross-contamination or to the purposeful addition of husk during processing. One cereal product, however, uses the macerated 
husk during its manufacture, namely beer. Not surprisingly, therefore, the Si content of beer appears to be high (Pennington, 1991; Bellia et al. 1994), although analytical data are not widely available.

Beer, therefore, is proposed to be a major contributor to Si intake in the Western diet (Pennington, 1991; Jugdaohsingh et al. 2002). Nutrient intakes do not necessarily reflect nutrient bioavailability but estimated data, based on urinary excretion, suggest that Si bioavailability from beer is relatively high (Bellia et al. 1994). However, the Si content of beer has not been well established while the bioavailability of $\mathrm{Si}$ from beer has not been studied in a controlled setting. Here we measured the $\mathrm{Si}$ content of seventy-six different beers and, then, using blood and urinary measurements in healthy volunteers, we estimated $\mathrm{Si}$ absorption from beer.

\section{Materials and methods}

\section{Materials}

Ultra-high-purity (UHP) water $(18 \mathrm{M} \Omega / \mathrm{cm})$ was from an Elga water purifier (Elga Ltd, High Wycombe, UK). Sodium silicate $\left(14 \% \mathrm{NaOH}\right.$ and $27 \% \mathrm{SiO}_{2}$ or $\left.6.9 \mathrm{M}-\mathrm{Si}\right)$ and $\mathrm{HCl}(5 \mathrm{M})$ were purchased from Aldrich Chemical Co. (Gillingham, UK). Nitric acid (65\% (w/v) $\mathrm{HNO}_{3}$ ) was high purity from Fluka Ltd (Gillingham, UK). Si standard solution (9800 mg Si/l) was from Aldrich Chemical Co. (Gillingham, UK). Ultrafree-4 centrifugal filter units (5000 nominal molecular-weight cut-off limit) were from Millipore UK Ltd (Watford, UK). These were each cleaned three times before use by centrifugation at $3000 \mathrm{rpm}(1500 \mathrm{~g})$ with UHP water $(4 \mathrm{ml})$ for $10 \mathrm{~min}$, which removes the glycerine preservative on the membrane. Intravenous indwelling cannulae $(1.2 \times 45 \mathrm{~mm})$ were from Johnson \& Johnson Medical (Pomezia, Italy). Syringes $(10 \mathrm{ml})$ were from Terumo Europe N.V. (Leuven, Belgium). Polypropylene tubes $(10 \mathrm{ml})$, pre-washed with UHP water and then dried before use, were from Medfor Products (Farnborough, UK). Polypropylene bottles were purchased from VWR International Ltd (Poole, UK). Polypropylene Mauser bottles (2.5 litres) for urine collection were from Aldrich Chemical Co. (Gillingham, UK) and these were cleaned with $10 \%$ (v/ v) $\mathrm{HNO}_{3}$ for $24 \mathrm{~h}$ and thoroughly rinsed with UHP water, before air-drying in a class $\mathrm{J}$ clean air room before use. Pasteur pipettes $(3.5 \mathrm{ml})$, used for serum transfer, were purchased from Greiner Bio-One Ltd (Stonehouse, UK).

Beer, containing $35(\mathrm{SD} 0 \cdot 5) \mathrm{mg} \mathrm{Si} / \mathrm{l}(4.6 \%$ (v/v) ethanol; Brakspear Live Organic) was a bottled ale from WH Brakspear \& Sons (Henley on Thames, UK). A solution of $4.6 \%$ (v/v) ethanol (pharmaceutical grade; St Thomas' Hospital Pharmacy, London, UK) with negligible Si contamination $(<0.02 \mathrm{mg} / \mathrm{l})$ was prepared on the day before its ingestion. A solution of orthosilicic acid (OSA) was prepared the day before the study by adding $450 \mu \mathrm{g}$ of the sodium silicate solution into 2.5 litres UHP water and by adjusting the $\mathrm{pH}$ to $7-7 \cdot 2$ with $5 \mathrm{M}-\mathrm{HCl}$ to give an approximate $\mathrm{Si}$ concentration of $35 \mathrm{mg} / \mathrm{l}$. The $\mathrm{pKa}$ of OSA is 9.4 so at $\mathrm{pH} 7.0$ (i.e. the OSA solution), very little is deprotonated. In beer, commonly with a $\mathrm{pH}$ of $4.5-6$, even less will be in the deprotonated form. Hence solution $\mathrm{pH}$ may have an effect on silicic acid speciation but upon entering the gastrointestinal tract (i.e. after ingestion) such differences in original speciation will be lost due to the large effect of digestive juice (i.e. luminal speciation will become similar). For these reasons, the different starting solution $\mathrm{pH}$ are unlikely to affect $\mathrm{Si}$ absorption greatly.

The exact concentration of $\mathrm{Si}$ in the OSA solution was later verified by inductively coupled plasma optical emission spectrometry (ICPOES) and the monomeric nature of the $\mathrm{Si}$ was confirmed by ultrafiltration (Jugdaohsingh et al. 2000) (see below and p. 406).

\section{Beer samples}

Beer samples ( $n$ 76) were collected as draught beer from licensed bars and public houses around the London area (UK) (approximately $10 \mathrm{ml}$ each; $n$ 19) into Si-free polypropylene tubes or were supplied in bottles or cans by the breweries from the UK ( $n$ 29), continental Europe ( $n$ 23) or Australia ( $n$ 5). The Si content of beer was analysed by ICPOES (see later; p. 405) using sample-based standards (i.e. beer spiked with $0-30 \mathrm{mg} \mathrm{Si} / \mathrm{l}$ ).

\section{Ultrafilterable silicon in beer}

To determine the fraction of monomeric (soluble) $\mathrm{Si}$ in beer, samples of beer used in the ingestion studies were ultrafiltered ( $n$ 4) as before (Jugdaohsingh et al. 2000). OSA solutions ( $n$ 4), matched for beer Si concentration, were similarly ultrafiltered as a positive control (about $95 \%$ Si expected to be ultrafilterable; Reffitt et al. 1999; Jugdaohsingh et al. 2000). Solutions of oligomeric silicic acid ( $n 4)$, which is an Si concentration-dependent polysilicate that is metastable in subsequently diluted solutions (Taylor et al. 1997), were also prepared as before (Jugdaohsingh et al. 2000). Solutions were matched for beer-Si concentration and their filterability determined as a negative control (about $10 \% \mathrm{Si}$ expected to be ultrafilterable). Previous work showed this method of ultrafiltration to be comparable with the molybdate assay for the determination of 'monomeric Si' in solution (Jugdaohsingh et al. 2000). It is recognised that, using either method, disilicic acid and very small oligomeric silicic acid species are also detected but these are in rapid equilibrium with monosilicic acid, so the term 'monomeric Si' is used.

All samples $(4 \mathrm{ml})$ were ultrafiltered by centrifugation at $3000 \mathrm{rpm}$ and the filtrates were collected into pre-weighed tubes and their final weights recorded. The filter membranes were then rinsed with UHP water to a final volume of $4 \mathrm{ml}$ and the contents again collected into preweighed tubes (termed retentate).

\section{Bioavailability of silicon}

Subject recruitment and study design. Seventeen healthy volunteers (nine males and eight females; mean age 25 (SD 7) years) with normal renal function, assessed by serum levels of creatinine (Clinical Biochemistry Laboratory, St Thomas' Hospital) were recruited by circular email from King's College London (London, UK). They avoided alcohol and high Si-containing foods (beer, cereals, and certain vegetables and fruit) $24 \mathrm{~h}$ before the 
study day. The subjects were warned of the effects of alcohol and the study was approved by King's College London local research ethics committee, and the subjects gave their written consent before investigation.

For practical reasons the subjects were studied as two separate groups, with nine subjects in group 1 (four females and five males) and eight subjects in group 2 (four females and four males). In group 1, four subjects ingested 0.6 litres beer (about three units of alcohol) on week 1 and the same volume of OSA solution on week 2. The other five subjects ingested the OSA solution on week 1 and beer on week 2 . In group 2, four subjects ingested 0.6 litres $4.6 \%(\mathrm{v} / \mathrm{v})$ ethanol (three units of alcohol) on week 1 and the same volume of water on week 2 , while the remaining four subjects ingested the water on week 1 and the ethanol solution on week 2 .

Blood and urine collections. Subjects fasted overnight from 23.30 hours before each study day. At 08.00 hours on day 1 (week 1), the fasted subjects emptied their bladder and thereafter collected urine for $3 \mathrm{~h}$ (i.e. $08.00-11.00$ hours) for a baseline Si measurement using a pre-weighed container. Subjects ingested 0.6 litres UHP water over this period and returned to their normal eating habits thereafter, but avoided alcohol and foods high in Si as they had done before the start of the study.

At 08.00 hours on day 2 (week 1), the same fasted subjects emptied their bladder and an indwelling cannula was inserted into a forearm vein. The subjects then ingested the solutions as noted above. Blood samples $(5 \mathrm{ml}$ each) were taken at baseline (two samples, $10 \mathrm{~min}$ apart) and then at $30 \mathrm{~min}$ intervals for $2 \mathrm{~h}$, and at $1 \mathrm{~h}$ intervals for the final $4 \mathrm{~h}$, following the ingestion of the solutions. The subjects collected urine in two $3 \mathrm{~h}$ collections from 08.00 hours (i.e. 08.00-11.00 hours and 11.00-14.00 hours) using separate pre-weighed containers. The subjects remained fasted during the $6 \mathrm{~h}$ period except for the ingestion of 0.6 litres UHP water during the last $3 \mathrm{~h}$ of the study period (11.00-14.00 hours).

Blood sample preparation. Clotted blood samples were centrifuged at $3000 \mathrm{rpm}$ for $10 \mathrm{~min}$ at $4^{\circ} \mathrm{C}$. Sera were separated into $10 \mathrm{ml}$ polypropylene tubes and stored at $-20^{\circ} \mathrm{C}$ until elemental analysis. All preparation was conducted in a class $\mathrm{C}$ laminar clean air cabinet.

Urine sample preparation. The urine samples were weighed and a $10-100 \mathrm{ml}$ homogeneous portion was collected into polypropylene bottles and diluted with equivolume $0.7 \%(\mathrm{v} / \mathrm{v}) \mathrm{HNO}_{3}(1: 1)$ to reduce any precipitation on storage (Burden et al. 1995). Diluted samples were stored at $4^{\circ} \mathrm{C}$ until elemental analysis.

\section{Elemental analysis}

Samples from the ultrafiltration studies and diluted sera, urine and beer samples from the absorption studies were analysed at least in duplicate for $\mathrm{Si}$ content by ICPOES (Jobin Yvon JY 24; Instruments SA, Longjumeau, France) with a V-groove nebuliser and a Scott-type double-pass spray chamber at $251.611 \mathrm{~nm}$. Analysis was by peak profile with a window size of $0.1 \mathrm{~nm}$, with fiftyfour increments per profile and an integration time of $0.5 \mathrm{~s}$ for ultrafiltration samples, beer and urine samples, and $0.3 \mathrm{~s}$ for sera (Reffitt et al. 1999). The sample flow rate was $1 \mathrm{ml} / \mathrm{min}$. Sample-based standard solutions were used (i.e. UHP water, beer, pooled diluted serum or pooled diluted urine samples were spiked with $\mathrm{Si}$ from a standard inductively coupled plasma solution). Serum samples were diluted (1:4) with $0.7 \%$ (v/v) $\mathrm{HNO}_{3}$ before analysis. The diluted urine samples were incubated in their closed containers at $40^{\circ} \mathrm{C}$ overnight which dissolved any urinary precipitate (Burden et al. 1995) and were then cooled to room temperature before analysis. Beer and samples from ultrafiltration studies were analysed without further treatment. Detection limits for $\mathrm{Si}$ were $5 \mu \mathrm{g} / \mathrm{l}$ in beer and ultrafiltration samples, $10 \mu \mathrm{g} / \mathrm{l}$ in diluted urine samples and $25 \mu \mathrm{g} / \mathrm{l}$ in diluted sera. Standard reference materials do not exist for $\mathrm{Si}$ in biological samples but recovery was assessed by spiking samples with known concentrations of $\mathrm{Si}$ and then preparing them for analysis. Recoveries were 99.5 (SD 2.6) \% for beer and 99.7 (SD 2.4) \% for urine (three different spiked samples each assessed in triplicate). Recovery was 102.8 (SD 9.4) $\%$ for serum samples (six different spiked samples each assessed in duplicate). Precision was 98.7 (SD 5.3) \% for $\mathrm{Si}$ in beer and 96.9 (SD 3.4) \% for $\mathrm{Si}$ in urine (percentage agreements of triplicate means for three different samples). Precision was 101.4 (SD 9.3) \% in serum (percentage agreements of duplicate means for six different samples).

\section{Sample size and statistical analysis}

Based upon previous findings (Jugdaohsingh et al. 2000) we anticipated that the urinary excretion of $\mathrm{Si}$ would be $53 \%$ following the ingestion of OSA with a standard deviation of $8.5 \%$. To observe a difference in urinary $\mathrm{Si}$ excretion of $10 \%$ (i.e. for OSA $v$. beer), eight subjects per group were required to achieve $80 \%$ power and $95 \%$ significance. Data are expressed as mean values and standard deviations unless otherwise indicated. We used one-way ANOVA to assess potential differences in the $\mathrm{Si}$ content of beer by geographical origin (UK $v$. continental Europe $v$. Australia) or by type of beer (wheat beer $v$. stout $v$. ale $v$. lager) or by storage and presentation type (bottled $v$. canned $v$. draught). Beers were categorised according to the description of the manufacturer. Wheat beers are those in which the raw materials included both wheat and malted (germinated) barley. Stouts are very darkly coloured and are made from roasted barley as well as barley malt. Ales are a golden brown colour and are made from predominantly ale-style barley malts. Finally lager, which is usually lighter in colour than ales, is made from lager-style barley malts and is the most widely consumed beer type in Europe. Significant differences in serum $\mathrm{Si}$ and urinary excretion of $\mathrm{Si}$, following the ingestion of the different test solutions, were determined by repeated measurement ANOVA which compared the effect of treatment over time in subjects acting as their own controls. Paired Student's $t$ tests were used to determine significant differences between the percentage excretion of urinary $\mathrm{Si}$ over $6 \mathrm{~h}$ following the ingestion of beer or OSA. A $P$ value $<0.05$ was considered significant and all statistical analyses were two-sided. SPSS software version 10.0.1 for Windows (SPSS Inc., Chicago, IL, USA) was used for all statistical analyses. 


\section{Results}

\section{Concentration of silicon in beer}

Fig. 1 shows the distribution of $\mathrm{Si}$ concentrations in the various beers. The mean level was 19.2 (SD 6.6) $\mathrm{mg} / \mathrm{l}$; the median level was $18.0 \mathrm{mg} / \mathrm{l}$. However, there were no significant differences in the $\mathrm{Si}$ levels of the different beers whether by geographical origin $(P=0.93$; data not shown) or by type of beer $(P=0.98$; Table 1$)$ or by type of storage and presentation $(P=0 \cdot 17$; Table 1$)$.

\section{Ultrafiltration of silicon from beer, orthosilicic acid and oligomeric silicic acid solution}

Of the $\mathrm{Si}$ in beer, 83 (SD 4) \% was ultrafilterable compared with 94 (SD 1) \% of Si from the OSA solution and only 10 (SD 1) \% of $\mathrm{Si}$ in the oligomeric silicic acid solution.

\section{Bioavailability of silicon}

The characteristics of the two groups were not significantly different, except for BMI, which was slightly higher in the OSA and beer group $\left(25.4(\mathrm{SD} 1.3) \mathrm{kg} / \mathrm{m}^{2}\right)$ than the ethanol and water group $\left(21.6(\mathrm{SD} 2 \cdot 2) \mathrm{kg} / \mathrm{m}^{2}\right)$. Subjects took a longer period of time to completely ingest the beer than the OSA solution (15-30 min compared with 5-10 min, respectively).

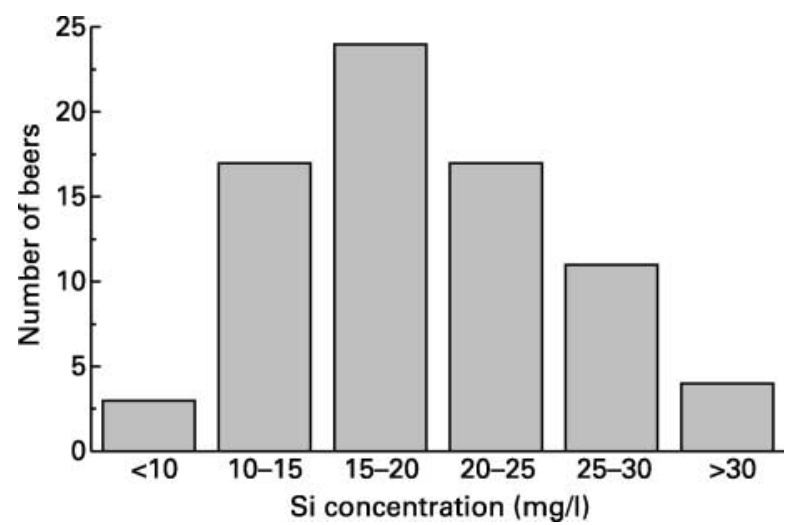

Fig. 1. Distribution of beer silicon levels $(n 76)$.

Table 1. Silicon content of beers $(n 76)$

(Mean values, standard deviations and ranges)

\begin{tabular}{|c|c|c|c|c|c|}
\hline \multirow[b]{2}{*}{ Beers* } & \multirow[b]{2}{*}{$n$} & \multirow{2}{*}{$\begin{array}{l}\text { Percentage } \\
\text { of total }\end{array}$} & \multicolumn{3}{|c|}{$\mathrm{Si}(\mathrm{mg} / \mathrm{l})$} \\
\hline & & & Mean & SD & Range \\
\hline Wheat beer & 2 & $2 \cdot 6$ & 19.5 & 4.3 & $16.5-22.5$ \\
\hline Stout & 3 & 3.9 & $20 \cdot 2$ & 10.9 & $9 \cdot 6-31.5$ \\
\hline Ale & 34 & 44.7 & 19.4 & $5 \cdot 7$ & $10 \cdot 1-35 \cdot 0$ \\
\hline Lager & 37 & $48 \cdot 7$ & $18 \cdot 9$ & 7.4 & $9 \cdot 0-39 \cdot 4$ \\
\hline Bottled & 30 & 39.5 & 18.5 & 6.7 & $10 \cdot 1-35 \cdot 0$ \\
\hline Canned & 26 & 34.2 & $18 \cdot 3$ & 6.0 & $9.0-28.9$ \\
\hline Draught & 20 & $26 \cdot 3$ & $21 \cdot 6$ & $7 \cdot 1$ & $11 \cdot 7-39 \cdot 4$ \\
\hline
\end{tabular}

${ }^{*}$ For definitions of beer types, see p. 405.
For all volunteers, the mean baseline serum $\mathrm{Si}$ concentration was 75 (SD 38) $\mu \mathrm{g} / \mathrm{l}$ (range $21-171 \mu \mathrm{g} / \mathrm{l}$ ) before ingestion of the test solutions, and this did not increase following the ingestion of either ethanol or UHP water (Fig. 2). Serum Si concentrations, however, markedly increased following ingestion of the OSA solution (21.5 mg Si by final analysis) or beer $(22.5 \mathrm{mg}$ Si by final analysis). Peak concentrations of $\mathrm{Si}$ were observed at $1 \mathrm{~h}$ after the ingestion of OSA (613 (SD 95) $\mu \mathrm{g} / \mathrm{l})$ and at $1.5 \mathrm{~h}$ after the ingestion of beer (713 (SD 121) $\mu \mathrm{g} / \mathrm{l})$. Repeated measurement ANOVA showed that the difference between serum Si levels following the ingestion of beer $v$. OSA, over the $6 \mathrm{~h}$ period, did not quite reach significance $(P=0.06$ for the effect of treatment; Fig. 2). Allowing for the small differences in the amount of ingested $\mathrm{Si}(22.5 \mathrm{mg}$ in beer v. $21.5 \mathrm{mg}$ in OSA), significance was reduced to $P=0.28$ (comparing by repeated measurement ANOVA ( $\mu \mathrm{g} \mathrm{Si} / \mathrm{l}$ plasma per $\mathrm{mg} \mathrm{Si}$ ingested); data not shown).

\section{Urinary silicon}

The mean baseline urinary excretion of Si before the ingestion of the test solutions was 0.8 (SD 0.5 ) $\mathrm{mg} / 3 \mathrm{~h}$ (Fig. 3). Urinary $\mathrm{Si}$ was significantly increased after the ingestion of the OSA solution and beer $(P<0 \cdot 005)$, whereas there was no change in urinary $\mathrm{Si}$ following the ingestion of either the ethanol solution or UHP water (Fig. 3). The maximum increase in urinary $\mathrm{Si}$ was observed within $3 \mathrm{~h}$ of the ingestion of either beer or OSA. The excretion of ingested $\mathrm{Si}$ in urine over the $6 \mathrm{~h}$ period from beer was 12.4 (SD 2.2) $\mathrm{mg}(55 \cdot 3$ (SD 9.7) \% of ingested dose) and was significantly greater than that from OSA (9.5 (SD 1.9) $\mathrm{mg}$, or 44.9 (SD 9.4) \% of ingested dose; $P<0.01$ ). However total urinary outputs over the same period (08.00-14.00 hours) tended towards a significant difference $(1.32(\mathrm{SD} 0.51)$ v. 1.04 (SD 0.36) litres; beer $v$. OSA; $P=0.08)$. Thus, after correcting for urinary output (i.e. comparing concentrations; $\mathrm{mg} \mathrm{Si} / \mathrm{l}$ urine) there was no difference in $\mathrm{Si}$ excretion between the groups $(P=0.73)$.

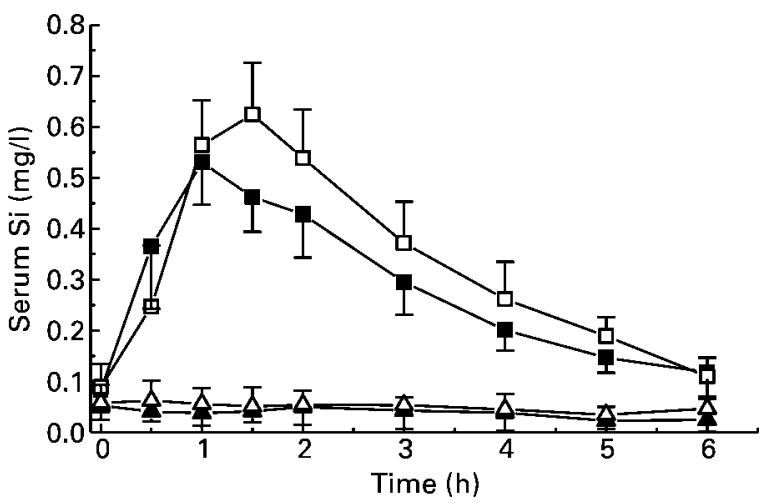

Fig. 2. Serum $\mathrm{Si}$ in eight subjects after the ingestion of orthosilicic

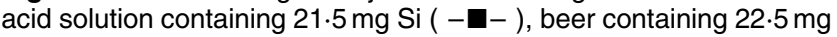
Si (- $\square-), 4.6 \%(v / v)$ ethanol solution containing $<0.02 \mathrm{mg} \mathrm{Si}(-\mathbf{\Delta - )}$, and ultra-high-purity water containing $<0.02 \mathrm{mg} \mathrm{Si}(-\triangle-)$. Values are means, with standard deviations represented by vertical bars. 


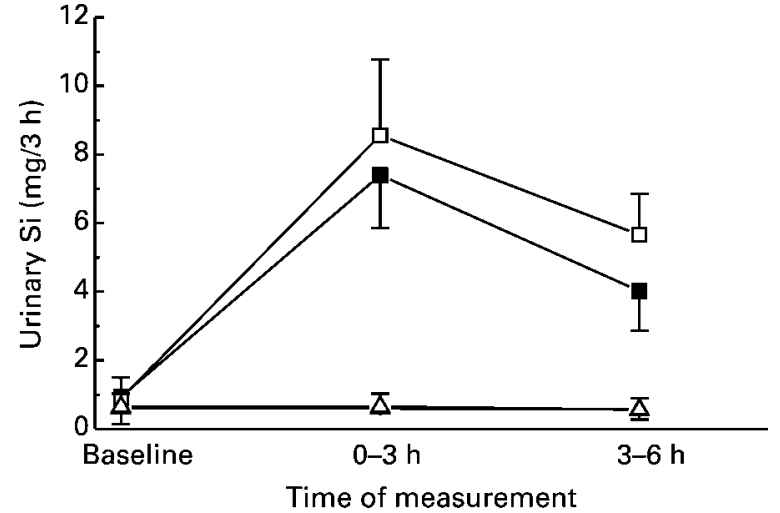

Fig. 3. Urinary $\mathrm{Si}(\mathrm{mg} / 3 \mathrm{~h})$ in eight subjects after the ingestion of

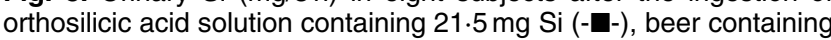
$22.5 \mathrm{mg} \mathrm{Si}(-\square-), 4.6 \%(\mathrm{v} / \mathrm{v})$ ethanol solution containing $<0.02 \mathrm{mg}$ Si (- $\Delta-)$, and ultra-high-purity water containing $<0.02 \mathrm{mg} \mathrm{Si}(-\triangle-)$. Values are means, with standard deviations represented by vertical bars.

\section{Discussion}

In the present study the Si content of beer varied from 9 to $39 \mathrm{mg} / \mathrm{l}$ although the reason for this variability is not clear. There was no association between the Si content of beer and the type of beer (i.e. stout, ale, lager, etc), the concentration of ethanol or country of origin. Si-based compounds may be used as clarifying agents (Hanssen \& Marsden, 1987) and/or as antifoaming agents (Dobbie \& Smith, 1982) during the production of beer, and thus a soluble fraction of $\mathrm{Si}$ could be retained in the final product. A more probable explanation, however, is that the Si content of beer, and the different levels of $\mathrm{Si}$ observed, are derived from the raw materials, namely barley and water. In particular the extent of $\mathrm{Si}$ dissolution from the macerated, malted barley could well determine the final beer $\mathrm{Si}$ levels and further work will confirm or refute this.

The annual per capita beer consumption varies between countries being, for example, 82 litres in the USA, 97 litres in the UK and 123 litres in Germany (Hoffmeister et al. 1999). Such intakes would account for about $20 \%$ of the average daily $\mathrm{Si}$ intake in these countries $(30 \mathrm{mg} / \mathrm{d}$; Bowen \& Peggs, 1984; Pennington, 1991; Uthus \& Seaborn, 1996; Jugdaohsingh et al. 2002). However, in Mediterranean-type countries Si intake from this source will be considerably lower as per capita beer consumption is 28.9 litres in Italy and 35.9 litres in France (Hoffmeister et al. 1999). Furthermore, the contribution of beer to dietary $\mathrm{Si}$ intake will vary greatly between individuals. For example, Pryer's nutritional survey (Pryer et al. 2001) recently showed that the median intake of beer and cider for men in the UK is 1.3 litres/week but the equivalent value is 0 in women. Although these absolute values differ to per capita estimates (Hoffmeister et al. 1999), the relative differences in intakes between men and women probably partly explain why the mean daily $\mathrm{Si}$ intake in men is higher than in women (Pennington, 1991; Jugdaohsingh et al. 2002).

The results from the present work show that $\mathrm{Si}$ is found in beer in a chiefly ultrafilterable form and that approximately $50 \%$ of beer-Si is readily absorbed in man. This, mostly, is then rapidly excreted by the kidneys. Moreover, findings were similar with a synthetic solution of OSA and consistent with previous data. Bellia et al. (1994) reported that $56 \%$ of $\mathrm{Si}$ in beer is excreted in urine within $8 \mathrm{~h}$ of ingestion. Similarly, Reffit et al. (1999) found that $53 \%$ of $\mathrm{Si}$ is excreted after the ingestion of OSA. Taken together, these findings suggest that $\mathrm{Si}$ is predominantly present in beer in a soluble, low-molecular-weight form which, as noted earlier (p. 403), is probably released from phytolythic forms during the hot mashing process of beer making (Bellia et al. 1994). The small difference observed between beer and OSA in the rate of appearance of $\mathrm{Si}$ in serum (Fig. 2) is probably related to the time it took to ingest these different solutions (see p. 406) or possibly due to the slower gastric emptying of beer.

The percentage excretion of $\mathrm{Si}$ in urine over the $6 \mathrm{~h}$ period following the ingestion of beer was greater than after the ingestion of OSA, but ethanol alone did not affect the mobilisation of $\mathrm{Si}$ from body stores (Figs. 2 and 3). The significant increase in urinary $\mathrm{Si}$ following beer ingestion compared with OSA was only partly mirrored by changes in serum $\mathrm{Si}$. We therefore looked at the effects of urinary output on $\mathrm{Si}$ excretion. We found that following the ingestion of beer (1.32 (SD 0.51) litres urine excreted) or ethanol (1.14 (SD 0.41 litres), urinary output tended to be greater over a $6 \mathrm{~h}$ period than following OSA (1.04 (SD 0.36 litres) or water (0.76 (SD 0.31 litres). Such observations are consistent with a diuretic effect of alcohol and hence suggest that freshly ingested Si may be more rapidly excreted when alcohol (i.e. beer) is coingested than when it is absent (i.e. OSA) (Fig. 3). Presumably much absorbed Si follows the water pool closely. A longer urinary collection period may have shown more equivalent $\mathrm{Si}$ excretion but this was not possible in fasting volunteers. Thus the present data suggest that the differences observed in urinary $\mathrm{Si}$ levels immediately following beer ingestion compared with OSA are mainly related to a diuretic effect of alcohol. Although a relatively small effect, it will need to be borne in mind in experiments where short-term urinary excretion is used as a proxy for $\mathrm{Si}$ absorption. Also, whether food affects the absorption of Si from beer will also need to be considered in further studies.

It should be noted that certain other foods also contribute high levels of bioavailable Si to the normal diet. In a recent study we showed that a mean of $41 \%$ of ingested $\mathrm{Si}$ appeared in urine over a $6 \mathrm{~h}$ period from foods high in Si which, typically, are natural waters, cereals and certain vegetables (Jugdaohsingh et al. 2002). However, the range was large; for example, bananas which are high in Si (about $5.4 \mathrm{mg} /$ portion) had very low bioavailability (about $5 \%$ ) while green beans, mineral water, rice and certain breakfast cereals had high bioavailability $(2 \cdot 3-4.6 \mathrm{mg} /$ portion and 41-86\% appearance in urine) (Jugdaohsingh et al. 2002). The finding that beer has an average Si level of $5.5 \mathrm{mg} /$ portion (half pint or $284 \mathrm{ml}$ in the UK) and that $55 \%$ of the $\mathrm{Si}$ appears in urine also places this beverage in the high Si-containing and high Si-bioavailability category of foods. However, we wish to emphasise that the consumption of alcoholic beverages, such as beer, should always be within the government-set daily accepted 
limits, which depend upon sex and age, and that increased intakes of alcoholic beverages should not be considered a way of increasing certain nutrient intakes. Alcohol abuse is associated with greatly increased morbidity and mortality including poor bone health (Yuan et al. 2001). Nonetheless, the moderate ingestion of alcohol is now well known to have a beneficial role in human health (for example, cardiovascular disease and CHD, and overall mortality; De Loromier, 2000). In terms of bone health, the moderate intake of alcohol has been shown to prevent bone loss in elderly men and women (Felson et al. 1995; Tunner \& Sibonga, 2001), by reducing bone resorption (Rapuri et al. 2000). However, since beer is a major source of bioavailable $\mathrm{Si}$, and dietary $\mathrm{Si}$ has been suggested to be important in bone formation (Tucker et al. 2001), a moderate intake of beer may also have an important anabolic effect on bone. Further work will need to dissect out the effects of alcohol per se on bone health $v$. other components, such as $\mathrm{Si}$, that are found at high levels in alcoholic beverages and especially beer. Interestingly, Si has also been shown to play a role in atherosclerosis, in preventing the formation of atheromatous lesions and aortic calcification (Schwarz, 1977; Loeper et al. 1988; McCarty, 1997) and, again, the effect of Si $v$. ethanol should be established in CHD.

In conclusion, beer contains about $19 \mathrm{mg} \mathrm{Si} / 1$, and serum and urinary Si levels significantly increased following the ingestion of beer, confirming this as a readily bioavailable source of $\mathrm{Si}$ and suggesting that $\mathrm{Si}$ is present as OSA. We also confirmed that moderate alcohol (ethanol) ingestion had no effect on Si mobilisation from body stores. Diets that are high in Si may contribute to beneficial effects on bone which, for moderate beer intake, may be in addition to, or separate from, the effect of ethanol. Further studies will address this issue.

\section{Acknowledgements}

S. S. was sponsored by a studentship from the Thai Government. We thank the Wellcome Trust for funding the ICPOES and the charitable grants committee of the Institute \& Guild of Brewing (UK) for running costs.

\section{References}

Bellia JP, Birchall JD \& Roberts NB (1994) Beer: a dietary source of silicon. Lancet 343, 235.

Bowen HJM \& Peggs A (1984) Determination of the silicon content of food. J Sci Food Agric 35, 1225-1229.

Broadhurst L (1999) Silicon's Elemental Benefits. Prolithic Sports. 800-969-6199. www.prolithic.com/hpages/ref_docs/ orthosil.html

Burden TR, Powell JJ \& Thompson RPH (1995) Optimal accuracy, precision and sensitivity of inductively coupled plasma optical emission spectrometry: bioanalysis of aluminium. JAAS 10, 259-266.

Carlisle EM (1986) Silicon as an essential trace element in animal nutrition. In Silicon Biochemistry Ciba Foundation Symposium, no. 121, pp. 123-139 [D Evered and M O’Connor, editors]. Chichester: John Wiley and Sons Ltd.

De Loromier AA (2000) Alcohol, wine, and health. Am J Surg 180, 357-361.
Dobbie JW \& Smith MJ (1982) Silicate nephrotoxicity in the experimental animal: the missing factor in analgesic nephropathy. Scott Med J 27, 10-16.

Eisinger J \& Clairet D (1993) Effects of silicon, fluoride, etidronate and magnesium on bone mineral density: a retrospective study. Magnes Res 6, 247-249.

Felson DT, Zhang Y, Hannan MT, Kannel WB \& Kiel DP (1995) Alcohol intake and bone mineral density in elderly men and women: the Framingham Study. Am $J$ Epidemiol 142, 485-492.

Hanssen M \& Marsden J (1987) E for Additives. Glasgow: Harper Collins Publishers.

Hoffmeister H, Schelp FP, Mensink GBM, Dietz E \& Boehning D (1999) The relationship between alcohol consumption, health indicators and mortality in the German population. Int J Epidemiol 28, 1066-1072.

Iler RK (1979) The Chemistry of Silica. Solubility, Polymerisation, Colloid and Surface Properties, and Biochemistry. New York: John Wiley \& Sons.

Jugdaohsingh R, Anderson SH, Tucker KL, Elliott H, Kiel DP, Thompson RP \& Powell JJ (2002) Dietary silicon intake and absorption. Am J Clin Nutr 75, 887-893.

Jugdaohsingh R, Reffitt DM, Oldham C, Day JP, Fifield LK, Thompson RP \& Powell JJ (2000) Oligomeric but not monomeric silica prevents aluminum absorption in humans. Am $J$ Clin Nutr 71, 944-949.

Jugdaohsingh R, Tucker KL, Qiao N, Cupples LA, Kiel DP \& Powell JJ (2004) Dietary silicon intake is positively associated with bone mineral density in men and premenopausal women of the Framingham Offspring Cohort. J Bone Miner Res (In the Press).

Loeper J, Goy J, Fragny M, Troniou R \& Bedu O (1988) Study of fatty acids in atheroma induced in rabbits by an atherogenic diet with or without silicon i.v. treatment. Life Sci 42, 2105-2112.

McCarty MF (1997) Reported antiatherosclerotic activity of silicon may reflect increased endothelial synthesis of heparan sulfate proteoglycans. Med Hypotheses 49, 175-176.

Nielsen FH (2002) Silicon nutrition affects urinary and plasma indicators of bone and connective tissue metabolism. In Macro and Trace Elements - Mengen - und Spurenelemente, pp. 1231-1237 [M Anke, R Muller, U Schafer and M Stoeppler, editors]. Leipzig, Germany: Schubert-Verlag.

Pennington JAT (1991) Silicon in foods and diets. Food Addit Contam 8, 97-118.

Pryer JA, Nichols R, Elliot P, Thrakrar B, Brunner E \& Marmot M (2001) Dietary patterns among a random sample of British adults. J Epidemiol Community Health 55, 29-57.

Rapuri PB, Gallagher JC, Balhorn KE \& Ryschon KL (2000) Alcohol intake and metabolism in elderly women. Am J Clin Nutr 72, 1206-1213.

Reffitt DM, Jugdaohsingh R, Thompson RPH \& Powell JJ (1999) Silicic acid: its gastrointestinal uptake and urinary excretion in man and effects on aluminium excretion. J Inorg Biochem 76, $141-147$.

Reffitt DM, Ogston N, Jugdaohsingh R, Cheung HF, Evans BA, Thompson RP, Powell JJ \& Hampson GN (2003) Orthosilicic acid stimulates collagen type 1 synthesis and osteoblastic differentiation in human osteoblast-like cells in vitro. Bone 32, 127-135.

Rico H, Gallego-Lago JL, Hernández ER, Villa LF, Sanchez-Atrio A, Seco C \& Gervas JJ (2000) Effect of silicon supplement on osteopenia induced by ovariectomy in rats. Calcif Tissue Int 66, 53-55.

Schwarz K (1977) Silicon, fibre, and atherosclerosis. Lancet i, 454-457.

Schwarz K \& Minle DB (1972) Growth-promoting effects of silicon in rats. Nature 239, 333-334. 
Taylor PD, Jugdaohsingh R \& Powell JJ (1997) Soluble silica with high affinity for aluminium under physiological and natural conditions. J Am Chem Soc 119, 8852-8856.

Tucker KL, Kiel DP, Powell JJ, Qiao N, Hannan MT \& Jugdaohsingh R (2001) Dietary silicon and bone mineral density: the Framingham Study. J Bone Miner Res 16, Suppl. 1, S510.

Tunner RT \& Sibonga JD (2001) Effects of alcohol use and estrogen on bone. Alcohol Res Health 25, 276-281.

Uthus EU \& Seaborn CD (1996) Deliberations and evaluations of the approaches, endpoints and paradigms for dietary recommendations of the other trace elements. $J$ Nutr $\mathbf{1 2 6}$, 2452S-2459S.

Van Dyck K, Van Cauwenbergh R, Robberecht H \& Deelstra H (1999) Bioavailability of silicon from food and food supplements. Fresenius J Anal Chem 363, 541-544.

Yuan Z, Dawdon N, Cooper GS, Einstadter D, Cebul R \& Rimm AA (2001) Effects of alcohol-related disease on hip fracture and mortality: a retrospective cohort study of hospitalized Medicare beneficiaries. Am J Public Health 91, 1089-1093. 